\title{
Slow Fashion in Indonesia: Drivers and Outcomes of Slow Fashion Orientations
}

\author{
Usep Suhud $^{1}$, Mamoon Allan ${ }^{2}$, Bayu Wiratama ${ }^{3} \&$ Ernita Maulida $^{1}$ \\ ${ }^{1}$ Universitas Negeri Jakarta, Indonesia \\ ${ }^{2}$ University of Jordan, Jordan \\ ${ }^{3}$ Universitas Negeri Semarang, Indonesia \\ Correspondence: Mamoon Allan, University of Jordan, Jordan. E-mail: m.allan@ju.edu.jo
}

Received: July 21, 2020

Accepted: September 22, 2020

Online Published: October 8, 2020

doi:10.5430/rwe.v11n6p27

URL: https://doi.org/10.5430/rwe.v11n6p27

\begin{abstract}
This study aims to measure the willingness to pay premium price in the case of slow fashion by employing consumers' slow fashion orientation, perceived valued, fashion involvement, and ethical purchase intention as predictor factors. Slow fashion is a fashion that is designed, produced, and consumed ethically by considering environmental, social, and humanitarian issues. Data were collected using an online survey and participants were approached conveniently. In total, 521 participants took part in this study consisting of 360 females and 161 males. The authors applied exploratory factor analysis and structural equation model to analyse the data. This study tested six hypotheses. As a result, slow fashion orientation significantly affected perceived value. Further, a perceived value significantly impacted fashion involvement, ethical purchase intention, and willingness to premium. Also, fashion involvement had a significant effect on ethical purchase intention, and ethical purchase intention had a significant influence on willingness to pay a premium price. This study shows a potential market of slow fashion in a developing country.
\end{abstract}

Keywords: slow fashion, perceived value, fashion involvement, ethical purchase intention, willingness to pay premium price

\section{Introduction}

The high demand for clothing gave rise to a clothing industry that can produce clothes quickly and cheaply. On the one hand, clothing manufacturing can be a solution. But on the other hand, there are many negative issues. Ping (2008) predicted that slow fashion can be a trend in the future and this trend is influenced by consumer value and lifestyle. Barnes, Lea-Greenwood, and Yan (2013) indicate that slow fashion encompasses apparel products that are prepared through environmentally, socially, and ethically responsible practices throughout the production cycle, which are generally made for offering basic designs and more long-lasting materials at higher prices.

Slow fashion "aims to assemble eco, ethical and sustainable fashion into one movement, in order to meet fundamental human needs, while allowing for the earth's natural regenerations to take place" (Cataldi, Dickson, \& Grover, 2010, p. 4). However, the slow fashion movement has not arisen with the cohesiveness of the slow food movement (Fletcher, 2010). Clark (2008) describes slow fashion as a collaborative method working along with the progress fashion system in line with the inclusion of three essential dimensions: valuing of local resources and economies; transparent production systems with fewer intermediations between producer and customer; and sustainable and sensorial products.

Kim, Choo, and Yoon (2013) reveal three main reasons why people avoid fast fashion including unmet expectation, symbolic incongruence, and ideological incompatibility. The unmet expectation includes poor performance, overly trendy style, big store discomfort, and lack of personal help. The symbolic incongruence includes deindividuation and inauthenticity. The ideological incompatibility includes irresponsibility and foreignness.

There is a movement that promotes slow fashion so that more consumers are willing to buy and put on these products. In Indonesia, the 'back to nature' movement has long been heard. The Government has special attention to the creation of a slow fashion ecosystem. They provide training on the use of natural dyes to business-people engaged in the textile sector, especially micro and small businesses (Khamelia, 2015). 
Sustainable fashion has attracted scholars to research this field of study. Some of the scholars focus on slow fashion. Slow fashion is claimed as a practice of sustainable fashion. Existing studies have gleaned consumer behaviour relating to slow fashion. For example, Jung (2014) initiated to examine the impact of customer orientation to slow fashion on perceived value. There are other terms closely relating to slow fashion, including sustainable fashion, green fashion, and ethical fashion. Characteristic of ethical fashion is the sustainable way entrepreneurs take care of social and environmental issues.

This study aims to measure the influence of slow fashion orientation, perceived value, and fashion involvement on ethical purchase intention and willingness to pay premium price. There are limited studies including these variables to predict ethical purchase intention and willingness to pay premium price in a quantitative approach in the case of slow fashion. Results of this current study are expected to broaden the study field of slow fashion consumption.

\section{Literature Review}

\subsection{Theoretical Background}

\subsubsection{Customer Orientation to Slow Fashion}

Fletcher (2007) illustrates slow fashion as stages of designing, producing, consuming and living better. Slow fashion is not time-based but quality-based. Slow is not the opposite of fast - there is no dualism - but a different approach in which designers, buyers, retailers and consumers are more aware of the impacts of products on workers, communities and ecosystems.

Shepard \& Pookulangara (2014) develop a model that can delineate a process of slow fashion. This process consists of three main steps, including design process, production process, and consumption process. This current study, however, focuses on the last process. In the consumption process, there are two prominent activities, namely sustainable retail and consumption in favour of long-term relationship and investment. This explanation is quite different with the one described by Štefko and Steffek (2018). These scholars develop a fashion matrix dividing fashion into slow and fast. This division is based on price, quality, cost of production, style, and service. According to them, slow fashion includes pret-a-porter, pret-a-couture, and houte couture.

In his study, Jung (2014). reveals the five dimensions of slow fashion orientation including equity, authenticity, functionality, localism, and exclusivity. Further, this scholar measures the influence of each these dimensions directly on perceived customer value. As a result, only exclusivity that significantly affects perceived value.

\subsubsection{Customer Value}

Zeithaml (1988) defines perceived value as the consumer's overall assessment of the usefulness of an item, service or other product category, based on perceptions of what the consumer receives and what the seller or service provider provides, or an exchange between perceived benefits and perceived costs. According to this author, the perceived value of the consumer is (a) a low price for the product they want, (b) everything desired by the consumer, (c) the quality corresponding to the price paid, and (d) things that consumers get from what they have provided.

In the study of Sweeney and Soutar (2001), perceived value has four dimensions including quality, emotion, price, and social. Petrick (2002) mentions the dimensions of perceived value include quality, emotional response, monetary price, behavioural price, and reputation.

Several studies document the effect of perceived value on other variables, such as perceived satisfaction and loyalty (Yang \& Peterson, 2004), product involvement and ethical fashion purchase intention (Hashmi, Abdullah, \& Anees, 2016). In this current study, perceived valued is linked to fashion involvement, ethical purchase intention, and willingness to pay a premium price.

Consumers choose slow fashion as they are influenced by "self-interest and personal values" (Karaosman, Morales-Alonso, \& Brun, 2014, p. 10). Further, scholars have connected personal value with ethical fashion consumption (Manchiraju \& Sadachar, 2014). Bhaduri and Stanforth (2017) employ clothing involvement and cues to predict customer perceived value. In their study, perceived value contains price value, social value, emotional value, and quality value.

\subsubsection{Fashion Involvement}

Prior studies have employed product involvement to predict various variables, for example, subjective product knowledge and consumer confidence (O'Cass, 2001). This scholar selects subjective knowledge, subjective expertise, confidence decision ability, and confidence to make right choice as predicted variables. Further, product involvement is applied by (Schivinski, Łukasik, \& Dabrowski, 2015) to test brand equity and purchase intention. In addition, 
(Hourigan \& Bougoure, 2012) predict recreational shopper identity, ongoing information search, market mavenism, and purchase decision involvement by using fashion clothing involvement as the predictor.

O'Cass (2001) applies fashion clothing involvement to predict fashion clothing product involvement and fashion clothing purchase decision involvement. Observing various studies above, some use 'product involvement' including 'fashion involvement' or 'fashion clothing involvement' whereas some other use 'consumer involvement'. In his study, O'Cass (2000) use consumer involvement instead which is used to assess product involvement, advertising involvement, purchase decision involvement, and consumption involvement. He claims product involvement is one of the consumer involvements dimensions. However, in this current study, the authors adopt 'fashion involvement' or 'fashion clothing involvement'.

\subsubsection{Ethical Purchase Intention}

Some consumers buy products not just because of the quality of the product, price, or other factors. However, sometimes consumers buy a product because of the value equation that he or she professes, with the value that the manufacturer by the product. For example, when a person loves the environment, he or she may have more appreciation for the environmentally friendly products that tend to buy the product. In the field of marketing, this behaviour is called ethical consumer behaviour (Schiffman \& Wisenblit, 2015).

Ethical consumer behaviour can be affected by ethical purchase intention. Ethical purchase intention can be affected by perceived risk, product knowledge, perceived quality, environmental concern, attitude towards purchase, and perceived value (Chen, Tsai, \& Hsieh, 2017; Maichum, Parichatnon, \& Peng, 2016). In the case of ethical fashion, ethical purchase intention is influenced by attitude towards buying ethical fashion (Pollari, 2016). According to Poldner (2013, p. 9) ethical fashion is "synonymously used with expressions such as green apparel, eco fashion, sustainable fashion and socially and environmentally friendly produced clothing."

Studies have explored ethical consumer behaviour in some cases, including the purchase of organic food (Young, Hwang, McDonald, \& Oates, 2010). Some others focus on the purchase of slow fashion products (Reimers, Magnuson, \& Chao, 2016)

\subsection{Theoretical Framework}

\subsubsection{Slow Fashion Orientation and Perceived Customer Value}

Jung and Jin (2014) say that customer orientation to slow fashion has five dimensions. These are equity, authenticity, functionality, localism, and exclusivity. Their study shows only exclusivity dimension has a significant influence on PCV. However, this current study links slow fashion orientation with perceived value without separating the dimensions.

\section{$H_{1}$ - Slow fashion orientation will have a significant impact on perceived customer value}

\subsubsection{Perceived Customer Value and Fashion Involvement}

Hashmi et al (2016) research the influence of personal value on product involvement. As well as the impact of product involvement on ethical fashion purchase intention. Although O'Cass (2000) mention that product involvement is a dimension of consumer involvement, however, product involvement can be used to represent consumer involvement. Hashmi et al. (2016) present that personal values significantly affect product involvement and ethical fashion purchase intention. Also, product involvement significantly influences ethical fashion purchase intention.

\subsubsection{Customer Value and Fashion Involvement}

$\mathrm{H}_{2}$ - Perceived customer value will have a significant effect on fashion involvement

Hashmi et al. (2016) research the influence of personal value on ethical fashion purchase intention. Based on their calculation, there is a significant impact of personal value on ethical fashion purchase intention. In addition, Wang, Yeh, and Liao (2013) look at the intention of consumer to purchase online content services. They use perceived value as mediator variable. They also select perceived usefulness, perceived enjoyment, technicality sacrifice, and perceived fee to be used for predicting perceived value. One of the findings they present that perceived value has a significant effect on purchase intention.

\subsubsection{Perceived Customer Value and Ethical Purchase Intention}

Furthermore, Taushif and Gupta (2013) measure the consumer intention to adopt mobile internet. They claim that perceived value significantly influences adoption intention. Schivinski et al. (2015) investigate the impact of perceived co-creation, perceived empowerment, perceive community, and perceived self-concept on consumer 
involvement relating to user-generated content (UGC). Further, they link involvement with UGI to brand equity and purchase intention. One of the findings they carry out was that involvement with UGI has a significant impact on purchase intention.

$\mathrm{H}_{3}$ - Perceived customer value will have a significant influence on ethical purchase intention

2.2.5 Perceived Customer Value and Willingness to Pay Premium

In the study of Zhang, Jahromi, \& Kizildag (2018), perceived customer value is linked to willingness to pay premium price. However, they split the three dimensions of perceived value as functional, social, and emotional value. These scholars show a significant effect of perceived value dimensions on willingness to pay premium price.

$\mathrm{H}_{4}$ - Perceived customer value will have a significant effect willingness to pay price premium

\subsubsection{Fashion Involvement and Ethical Purchase Intention}

Shang, Chen, and Shen (2005) measure the consumer intention relating to shopping online by applying the technology acceptance model. They fashion involvement as additional predictor. They show a significant effect of fashion involvement on online purchase intention. Furthermore, taking place in Pakistan, Rahman, Saleem, Akhtar, Ali, \& Khan (2014) investigate the influence of fashion innovativeness, consumer innovativeness, fashion involvement, and social values on intention to adopt new fashion. One of the findings they carry out is that fashion involvement significantly affect new fashion adoption intention.

$\mathrm{H}_{5}-$ Fashion involvement will have a significant impact on ethical purchase intention

\subsubsection{Ethical Purchase Intention and Willingness to Pay Premium}

Some studies employ purchase intention and willingness to pay premium price in their proposed models. However, there are limited studies testing the impact of purchase intention, particularly ethical purchase intention, on willingness to pay premium price. Hultman, Kazeminia, and Ghasemi (2015) measure the intention of tourists to be involved in ecotourism and its impact on willingness to pay premium price. They show a significant influence of ecotourism intention on willingness to pay premium price. Hashmi et al. (2016) study the impact of personal value on product involvement on ethical fashion purchase intention. They claim that product involvement has a significant effect on ethical fashion purchase intention.

Jung and Jin (2014) examine the effect of purchase intention on willingness to pay premium. They state that purchase willingness significantly influences willingness to pay premium price. Furthermore, Choi et al. (2012) examine the impact of ethical fashion on consumer behaviour. These researchers linked willingness to pay a premium with a higher willingness to pay for products from socially responsible business (SRB) and environmentally responsible business (ERB).

$\mathrm{H}_{6}$ - Ethical purchase intention will have a significant effect on willingness to pay price premium

Based on the studies discussed above, these hypotheses have been formulated. Figure 1 is the proposed model to be measured, built using the hypotheses statements.

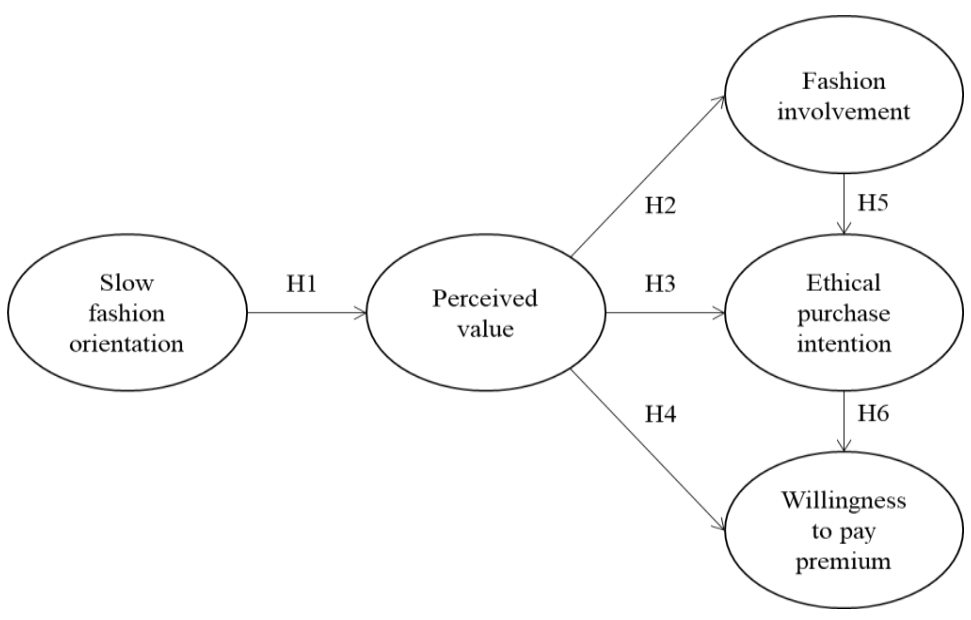

Figure 1. The proposed research model 


\section{Methods}

\subsection{Sample}

There were no specific criteria in recruiting participants for this current study. They were chosen using a convenient sampling technique. Participants were approached and asked using an online application platform to complete an online survey. Once they agreed, the link was given. In total, there were 521 usable data and it was almost $90 \%$ participants completed the questionnaire.

\subsection{Measures}

In total, there were five variables included in this current study. Indicators from previous studies were adapted to measure all the variables. Slow fashion orientation, ethical purchase intention, and willingness to pay premium were measured using indicators adapted from Jung (2014). Indicators from O'Cass (2004) were adapted to measure fashion involvement, and indicators from Sweeney and Soutar (2001) were adapted to measure perceived value.

\subsection{Data Analysis}

The authors analysed the quantitative data in three stages. In the first stage, the authors ran the SPSS program and operated exploratory factor analysis (EFA). This EFA is aimed to develop dimensions of variables and sustain only valid indicators. A valid indicator should have factor loadings of 0.4 or larger. This stage aims to establish the dimensions of each variable if it exists and maintains valid indicators. Valid indicators should have factor loadings of 0.4 or more. According to (Hair, Black, Babin, Anderson, \& Tatham, 2006) the score of 0.4 related to the number of participants. In this current study, total of the participants was 521, and 0.4 for factor loadings was manageable.

In the second stage, a reliability test was applied on constructs of each variable. The authors decided to follow (Hair et al., 2006) for selecting only constructs with Cronbach's alpha scores of 0.7 that were included in hypotheses testing.

In the third stage, the proposed model was tested using structural equation model (SEM). By applying SEM, the authors built a fitted model. To obtain a fitted model, indicators of each construct were eliminated. A fitted model must have a probability score of 0.05 (Schermelleh-Engel, Moosbrugger, \& Müller, 2003) and CMIN/DF score of $\leq$ 2 (Tabachnick, Fidell, \& Ullman, 2007). Additionally, a fitted model also must have a CFI score of $\geq 0.97$ (Li-tze Hu $\&$ Bentler, 1995) and RMSEA score of $\leq 0.05$ (Li-tze Hu \& Bentler, 1999).

\section{Results and Discussion}

\subsection{Participants}

Table 1 shows the profile of the participants of this current study. This study attracted 521 participants with 360 females $(69.1 \%)$ and 161 males (30.9\%). In term of level of education, they had completed, predominant of participants $(62.6 \%)$ held a high school certificate, and it was followed by those who held an under-grad certificate $(26.1 \%)$. Further, predominantly, participants were under 20 years old $(42.6 \%)$ and unmarried participants $(80.4 \%)$. Most of them worked full time (46.4\%).

Table 1. Profile of participants

\begin{tabular}{llcc}
\hline & & Frequency & Percent \\
\hline Sex & Female & 360 & 69.1 \\
& Male & 161 & 30.9 \\
Education level completed & Total & 521 & 100.0 \\
& Less than high & 13 & 2.5 \\
& High school & 326 & 62.6 \\
& Diploma & 41 & 7.9 \\
& Under-grad & 136 & 26.1 \\
Age & Post-grad & 5 & 1.0 \\
& $<20$ & 222 & 42.6 \\
& $20-24$ & 178 & 34.2 \\
& $24-29$ & 46 & 8.8 \\
& $30-34$ & 33 & 6.3 \\
& $35-39$ & 4 & .8 \\
\hline & $40-44$ & 18 & 3.5 \\
\hline
\end{tabular}




\begin{tabular}{llcc}
\hline & $45-49$ & 13 & 2.5 \\
Marital status & 50 and older & 7 & 1.3 \\
& Married & 94 & 18.0 \\
& Separated & 2 & .4 \\
& Unmarried & 419 & 80.4 \\
Occupational status & 6 & 1.2 \\
& Widow/widower & 242 & 46.4 \\
& Full-time & 178 & 34.2 \\
& Part-time & 82 & 15.7 \\
& Self-employed & 2 & .4 \\
& Unemployed & 17 & 3.3 \\
& Looking for a job & 521 & 100.0 \\
\hline
\end{tabular}

\subsection{Validity and Reliability Tests}

Table 2 presents the result of EFA analysis. Fashion involvement formed two dimensions. The first dimension consisted of nine indicators with a Cronbach's alpha score of 0.937 and the second dimension contained three indicators with a Cronbach's alpha score of 0.677 . Further, fashion involvement had nine indicators with Cronbach's alpha score of 0.937. Perceived value shaped three dimensions. These dimensions had six, two, and five indicators respectively. They had Cronbach's alpha scores of $0.833,0.821$, and 0.773 respectively. Further, ethical purchase intention consisted of two indicators with a Cronbach's alpha score of 0.755 . Lastly, willingness to purchase premium survived four indicators with a Cronbach's alpha score of 0.784 .

Table 2. Result of EFA analysis

\begin{tabular}{|c|c|c|c|}
\hline & Indicators & \multicolumn{2}{|c|}{$\begin{array}{l}\text { Factor Cronbach's } \\
\text { Loadings alpha }\end{array}$} \\
\hline & Slow fashion (1) & & 0.729 \\
\hline 1SF4 & I appreciate clothes made with traditional techniques & 0.778 & \\
\hline SF3 & $\begin{array}{l}\text { I believe that the clothing made from materials produced by } \\
\text { domestic companies is more valuable }\end{array}$ & 0.705 & \\
\hline SF5 & I prefer a simple clothing design & 0.702 & \\
\hline SF9 & We need to support the brand-they are domestic clothing & 0.610 & \\
\hline SF7 & I prefer to buy clothes made in Indonesia & 0.608 & \\
\hline SF6 & $\begin{array}{l}\text { Handmade apparel is more valuable than mass produced } \\
\text { Slow fashion (2) }\end{array}$ & 0.443 & 0.677 \\
\hline SF1 & I am very interested in clothing produced in limited quantities & 0.815 & \\
\hline SF2 & I am enjoying a clothing model that others do not enjoy & 0.773 & \\
\hline & $\begin{array}{l}\text { Clothes produced in limited quantities have a special appeal to me } \\
\text { Fashion involvement }\end{array}$ & 0.710 & 0.937 \\
\hline F6 & For me personally, fashion is an important product & 0.870 & \\
\hline F4 & Fashion is important to me & 0.860 & \\
\hline $\mathrm{F} 1$ & Fashion means a lot to me & 0.838 & \\
\hline F9 & Fashion is an important part of my life & 0.822 & \\
\hline F7 & I think a lot about fashion & 0.814 & \\
\hline F3 & I am very involved in fashion & 0.805 & \\
\hline F5 & I am interested in fashion & 0.798 & \\
\hline $\mathrm{F} 2$ & I found fashion as a very relevant product in my life & 0.790 & \\
\hline F8 & I regard fashion as a major part of my life & 0.788 & \\
\hline & Perceived value (1) & & 0.833 \\
\hline V4 & Clothes that will make me feel good & 0.830 & \\
\hline V3 & Clothes that will help me feel welcome in the community & 0.820 & \\
\hline
\end{tabular}


\begin{tabular}{lll}
\hline V6 & Clothes that will give me pleasure & 0.761
\end{tabular}

V5 Clothes that will make me relax while wearing them 0.761

V9 Clothes that I can enjoy while wearing them 0.608

V2 Clothes that will have a good impression for others $\quad 0.524$

Perceived value (2)

$\begin{array}{ll}\text { V11 Clothes that have a poor working process } & 0.899\end{array}$

V10 Clothes that will not last long $\quad 0.885$

Perceived value (3)

V13 Clothes that have acceptable quality standards $\quad-0.841$

V15 Clothes that well-made outfit $\quad-0.790$

V14 Clothes that have a value $\quad-0.767$

V7 Clothes that have consistent quality $\quad-0.557$

V12 Clothes that will make me want to wear it $\quad-0.511$

Intention to purchase slow fashion

IN2 I will buy clothes that are produced responsibly 0.899

IN1 There is a strong possibility that I will buy clothes that are 0.899 produced responsibly

Willingness to purchase premium

W2 I plan on buying clothes from socially responsible clothing sellers

W3 I am willing to pay a higher price for clothing produced in accordance with sustainable garment production standards

W4 I plan to buy clothes from a clothing store that is environmentally responsible

W1 I am willing to pay a higher price for clothing produced in accordance with a fair labour standards law

0.809

0.786

0.782

0.777
0.821

0.773

0.755

0.784

\subsection{Hypotheses Test}

Figure 2 demonstrates a structural model of hypotheses testing. This model achieved a fitness with a probability score of 0.416, CMIN/DF score of 1.030, CFI score of 0.999, and RMSEA score of 0.091 .

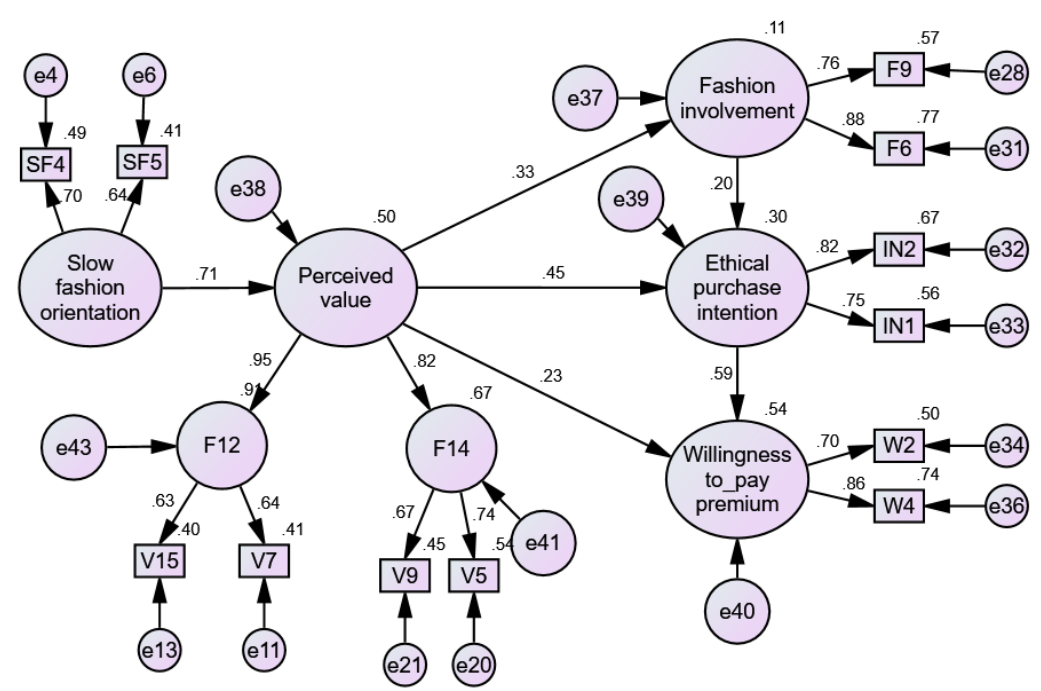

Figure 1. The structural model of the hypotheses testing

Table 3 presents results of the hypotheses testing. In total there were six hypotheses examined. All hypotheses obtained a C.R. score greater than 2.0 indicating significances. 
Table 3. Summary results of the hypotheses testing

\begin{tabular}{lllllll}
\hline & & & C.R. & P & Result \\
\hline $\mathrm{H}_{1}$ & Slow fashion orientation & $\rightarrow$ & Perceived value & 7.452 & $* * *$ & Accepted \\
$\mathrm{H}_{2}$ & Perceived value & $\rightarrow$ & Fashion involvement & 5.369 & $* * *$ & Accepted \\
$\mathrm{H}_{3}$ & Perceived value & $\rightarrow$ & Ethical purchase intention & 6.495 & $* * *$ & Accepted \\
$\mathrm{H}_{4}$ & Perceived value & $\rightarrow$ & Willingness to pay premium & 3.547 & $* * *$ & Accepted \\
$\mathrm{H}_{5}$ & Fashion involvement & $\rightarrow$ & Ethical purchase intention & 3.375 & $* * *$ & Accepted \\
$\mathrm{H}_{6}$ & Ethical purchase intention & $\rightarrow$ & Willingness to pay premium & 7.940 & $* * *$ & Accepted \\
\hline
\end{tabular}

\subsection{Discussion}

Collectively, the consumer perceived value construct is a very significant element in the consumer value literature, and it has been considered as one of the most important measures for earning a competitive advantage (Demirgünescedil, 2015). Previously, Jung (2014) mentioned slow fashion orientation had five dimensions. These five dimensions were used to predict customer perceived value. Although adapting the same indicators promoted by Jung (2014), this study resulted only two dimensions instead. However, this study brought an innovation by measuring the impact of slow fashion orientation without splitting the dimensions on perceived customer values as conducted by Jung and Jin (2016).

The first hypothesis predicted the effect of slow fashion orientation on perceived value. The SEM calculation produced a C.R. score of 7.452. In general, fashion orientation can affect mall personality, credit card use, shopping value, and convulsive buying (Park \& Burns, 2005; O. Rahman, Wong, \& Yu, 2016). Many consumers have a certain fashion orientation. However, not all of them have a slow fashion orientation. As previously predicted, this study agrees with what has been reported by previous studies (Jung \& Jin, 2016; O. Rahman et al., 2016) regarding the important role of fashion orientation towards shopping value. Consumers who are oriented towards slow fashion will prioritize their values to execute perceptions before the product purchase process. For these consumers, value becomes one of the guardians before they take further action.

In this study, perceived value played a major role in measuring three other variables. In the second hypothesis, third hypothesis, and fourth hypothesis, perceived value predicts fashion involvement, ethical purchase intention, and willingness to pay premium, respectively. These three hypotheses are significant with the C.R. 5,369, 6,495, and 3,547, respectively. As documented by Hashmi, Abdullah, and Anees (2016) document, perceived value affected fashion involvement. According to Sullivan, Kang, and Heitmeyer (2012), better understanding how consumer perceived value and involvement affect their patronage behaviour assists retailers' segment and market to consumers worldwide. However, Eroglu, Machleit, and Davis (2003) indicated that consumer involvement was connected to consumer perceived value. Whereas Tigert, Ring, and King (1976) postulate that consumer involvement helps to understand the fashion behavioural intentions and market segmentation. In the study of Jung and Jin (2014), perceived valued significantly influenced ethical purchase intention. Ethical purchase intention is often employed in research on green products and corporate social responsibility activities (Carrington, Neville, \& Whitwell, 2010; Isa, Chin, \& Liew, 2019).

Furthermore, the fifth hypothesis tested the impact of fashion involvement on ethical purchase intention. This path achieved a C.R. score of 3.375 indicating a significance. This finding is relevant with existing studies (Hashmi et al., 2016; Rahman, Mohamed, Rezai, Shamsudin, \& Sharifuddin, 2014; Shang, Chen, \& Shen, 2005). Thus, Hashmi et al. (2016) suggested that product involvement and individuals have a positive intention to purchase ethical fashion products. Previous studies have shown the effect of fashion involvement on purchase intention. In the case of slow fashion, fashion involvement creates ethical purchase intention. As previously mentioned, slow fashion products are only in demand by a group of consumers, who not only enjoy the beauty and function of these products, but also consider how the manufacturing process is and the impact of the manufacturing process of these products.

The sixth hypothesis assessed the effect of ethical purchase intention on willingness to pay premium price. The path gained a C.R. score of 7.940. This finding supports the studies of Hultman et al. (2015) and Jung and Jin (2016). In the same vein, Kim and Lee (2018) state that "customers have a willingness to pay a price premium for ethical purchasing behaviour, so that a strategy for extending supply chain management sustainability can lead to financial performance". 


\section{Conclusion}

This study aimed at measuring the impact of slow fashion orientation, perceived value, fashion involvement, and ethical purchase intention on willingness to pay premium price. The findings indicated a significant effect of slow fashion orientation on perceived value and a significant impact of perceived value on fashion involvement ethical purchase intention, and willingness to pay premium price. Further, there was a significant influence of fashion involvement on ethical purchase intention and a significant effect of ethical purchase intention on willingness to pay premium.

The findings of this study have significant implications for the understanding of slow fashion perception and involvement. According to Pookulangara and Shephard (Pookulangara \& Shephard, 2013), earlier studies have suggested that customers do not feel that they have enough knowledge about slow fashion to do an informed purchase (Pookulangara \& Shephard, 2013). Additionally, the pertinent literature indicates that the issue of slow fashion in Indonesia has received little attention, therefore, the findings add to our understanding of the slow fashion movement in Indonesia.

In this study, respondents were chosen conveniently. This technique can be considered as one of the limitations of this study, which, convenient sampling cannot generalise the results of the study. The scope of tourists' locations was restricted to consumers in Indonesia. Thus, this research concentrated on case studies in Indonesia, which rather deters the generalization of the research findings.

The findings of this study have a number of implications for future practice. A further study could investigate the relationship between slow fashion dimensions with the different demographic variables. Further research might explore the differences and difference of slow fashion perception and involvement between cultures or countries. Further studies need to be carried out to in order to explore the different motives and attitudes for consumers seeking slow fashion products.

\section{Acknowledgement}

This article was produced from a study funded by the Institute for Research and Community Service (LPPM), Universitas Negeri Jakarta, Indonesia.

\section{References}

Barnes, L., Lea-Greenwood, G., Watson, M. Z., \& Yan, R. (2013). An exploratory study of the decision processes of fast versus slow fashion consumers. Journal of Fashion Marketing and Management: An International Journal.

Bhaduri, G., \& Stanforth, N. (2017). To (or not to) label products as artisanal: effect of fashion involvement on customer perceived value. Journal of Product \& Brand Management.

Carrington, M. J., Neville, B. A., \& Whitwell, G. J. (2010). Why ethical consumers don't walk their talk: Towards a framework for understanding the gap between the ethical purchase intentions and actual buying behaviour of ethically minded consumers. Journal of Business Ethics, 97(1), 139-158.

Cataldi, C., Dickson, M., \& Grover, C. (2010). Slow fashion: Tailoring a strategic industry approach towards sustainability. Blekinge Institute of Technology.

Chen, H.-S., Tsai, B.-K., \& Hsieh, C.-M. (2017). Determinants of consumers' purchasing intentions for the hydrogen-electric motorcycle. Sustainability, 9(1447), 1-12.

Clark, H. (2008). SLOW+ FASHION—an Oxymoron—or a Promise for the future...?. Fashion Theory, 12(4), 427-446.

Demirgünescedil, B. K. (2015). Relative importance of perceived value, satisfaction and perceived risk on willingness to pay more. International Review of Management and Marketing, 5(4).

Eroglu, S. A., Machleit, K. A., \& Davis, L. M. (2003). Empirical testing of a model of online store atmospherics and shopper responses. Psychology \& Marketing, 20(2), 139-150.

Fletcher, K. (2007). Slow fashion. Retrieved from https://theecologist.org/2007/jun/01/slow-fashion

Fletcher, K. (2010). Slow fashion: An invitation for systems change. Fashion Practice, 2(2), 259-265.

Hair, J. F., Black, W. C., Babin, B. J., \& Anderson, R. E. (2019). Multivariate data analysis (8th ed.). Hampshire, UK: Cengage Learning.

Hashmi, M. S., Abdullah, F., \& Anees, M. (2016). Impact of personal values on ethical fashion purchase intention: mediating effect of product involvement. Pakistan Journal of Psychological Research, 31(2). 
Hourigan, S. R., \& Bougoure, U.-S. (2012). Towards a better understanding of fashion clothing involvement. Australasian Marketing Journal (AMJ), 20(2), 127-135.

Hu, Li-tze, \& Bentler, P. M. (1995). Structural equation modeling: Concepts, issues, and applications. In R. H. Hoyle (Ed.), Evaluating model fit (pp. 76-99). London: Sage.

Hu, Li-tze, \& Bentler, P. M. (1999). Cutoff criteria for fit indexes in covariance structure analysis: Conventional criteria versus new alternatives. Structural Equation Modeling: A Multidisciplinary Journal, 6(1), 1-55.

Hultman, M., Kazeminia, A., \& Ghasemi, V. (2015). Intention to visit and willingness to pay premium for ecotourism: The impact of attitude, materialism, and motivation. Journal of Business Research, 68(9), 1854-1861.

Isa, S. M., Chin, P. N., \& Liew, I. (2019). Exploring the role of corporate social responsibility skepticism in ethical purchase intention. Social Responsibility Journal.

Jung, S. (2014). Slow fashion: Understanding potential consumers and creating customer value for increasing purchase intention and willingness to pay a price premium. The University of North Carolina at Greensboro.

Jung, S., \& Jin, B. (2014). A theoretical investigation of slow fashion: Sustainable future of the apparel industry. International Journal of Consumer Studies, 38(5), 510-519.

Jung, S., \& Jin, B. (2016). Sustainable development of slow fashion businesses: Customer value approach. Sustainability, 8(6), 540.

Karaosman, H., Morales-Alonso, G., \& Brun, A. (2014). Slow fashion and sustainability in Spain: How can local manufacturing improve sustainability and how do consumers respond. 1st Annual EDIM PhD Conference, Milan.

Khamelia. (2015, August 20). Perajin Batik Pangkalpinang Dilatih Mengenal Zat Pewarna Alam (Pangkal Pinang batik crafters trained to know natural dyes). Retrieved from https://bangka.tribunnews.com/2015/08/20/perajin-batik-pangkalpinang-dilatih-mengenal-zat-pewarna-alam

Kim, Hyunsoo, \& Lee, C. W. (2018). The effects of customer perception and participation in sustainable supply chain management: A smartphone industry study. Sustainability, 10(7), 2271.

Kim, H., Choo, H. J., \& Yoon, N. (2013). The motivational drivers of fast fashion avoidance. Journal of Fashion Marketing and Management, 17(2), 243-260.

Maichum, K., Parichatnon, S., \& Peng, K.-C. (2016). Application of the extended theory of planned behavior model to investigate purchase intention of green products among Thai consumers. Sustainability, 8(10), 1077.

Manchiraju, S., \& Sadachar, A. (2014). Personal values and ethical fashion consumption. Journal of Fashion Marketing and Management.

O'Cass, A. (2000). An assessment of consumers product, purchase decision, advertising and consumption involvement in fashion clothing. Journal of Economic Psychology, 21(5), 545-576.

O'Cass, A. (2004). Fashion clothing consumption: antecedents and consequences of fashion clothing involvement. European Journal of Marketing.

Park, H., \& Burns, L. D. (2005). Fashion orientation, credit card use, and compulsive buying. Journal of Consumer Marketing.

Petrick, J. F. (2002). Development of a multi-dimensional scale for measuring the perceived value of a service. Journal of Leisure Research, 34(2), 119-134.

Ping, X. (2008). Fast, enjoyable, elegant and slow_-Future fashion trend influenced by new value system and life style. Art \& Design, (10), 52.

Poldner, K. (2013). Un-dress: Stories of Ethical Fashion Entrepreneuring. Difo Druck GmbH.

Pollari, M. (2016). Consumer's purchase intention of ethical fashion. Examining beliefs about fashion industry and attitudes towards ethical fashion.

Pookulangara, S., \& Shephard, A. (2013). Slow fashion movement: Understanding consumer perceptions-An exploratory study. Journal of Retailing and Consumer Services, 20(2), 200-206.

Rahman, O., Wong, K. K.-K., \& Yu, H. (2016). The effects of mall personality and fashion orientation on shopping value and mall patronage intension. Journal of Retailing and Consumer Services, 28, 155-164. 
Rahman, R. A., Mohamed, Z., Rezai, G., Shamsudin, M. N., \& Sharifuddin, J. (2014). Exploring the OIC food manufacturer intention towards adopting Malaysian halal certification. American Journal of Food Technology, $9(5), 266-274$.

Reimers, V., Magnuson, B., \& Chao, F. (2016). The academic conceptualisation of ethical clothing. Journal of Fashion Marketing and Management: An International Journal.

Schermelleh-Engel, K., Moosbrugger, H., \& Müller, H. (2003). Evaluating the fit of structural equation models: Tests of significance and descriptive goodness-of-fit measures. Methods of Psychological Research Online, 8(2), 23-74.

Schiffman, L. G., \& Wisenblit, J. (2015). Consumer behaviour (11th ed.). New Jersey: Pearson Education, Inc.

Schivinski, B., Łukasik, P., \& Dabrowski, D. (2015). User-generated images and its impact on consumer-based brand equity and on purchase intention. Logistyka, (2), 1054-1061.

Shang, R.-A., Chen, Y.-C., \& Shen, L. (2005). Extrinsic versus intrinsic motivations for consumers to shop on-line. Information \& Management, 42(3), 401-413.

Shepard, A., \& Pookulangara, S. (2014). The slow fashion process: Rethinking strategy for fast fashion retailers. Fast Fashion Systems: Theory and Applications, Londres, 4, 9-22.

Štefko, R., \& Steffek, V. (2018). Key Issues in slow fashion: Current challenges and future perspectives. Sustainability, 10(7), 2270.

Sullivan, P., Kang, J., \& Heitmeyer, J. (2012). Fashion involvement and experiential value: Gen Y retail apparel patronage. The International Review of Retail, Distribution and Consumer Research, 22(5), 459-483.

Sweeney, J. C., \& Soutar, G. N. (2001). Consumer perceived value: The development of a multiple item scale. Journal of Retailing, 77(2), 203-220.

Tabachnick, B. G., Fidell, L. S., \& Ullman, J. B. (2007). Using multivariate statistics (Vol. 5). Pearson Boston, MA.

Taushif, M. R., \& Gupta, M. (2013). A study of factors affecting impulase buying behaviour of consumers at malls (Delhi). International Journal of Research and Development -A Management Review (IJRDMR) ISSN (Print, 2(2), 46-50.

Tigert, D. J., Ring, L. J., \& King, C. W. (1976). Fashion involvement and buying behavior: A methodological study. ACR North American Advances.

Wang, Y.-S., Yeh, C.-H., \& Liao, Y.-W. (2013). What drives purchase intention in the context of online content services? The moderating role of ethical self-efficacy for online piracy. International Journal of Information Management, 33(1), 199-208.

Young, W., Hwang, K., McDonald, S., \& Oates, C. J. (2010). Sustainable consumption: green consumer behaviour when purchasing products. Sustainable Development, 18(1), 20-31.

Zeithaml, V. A. (1988). Consumer perceptions of price, quality, and value: a means-end model and synthesis of evidence. Journal of Marketing, 52(3), 2-22.

\section{Copyrights}

Copyright for this article is retained by the author(s), with first publication rights granted to the journal.

This is an open-access article distributed under the terms and conditions of the Creative Commons Attribution license (http://creativecommons.org/licenses/by/4.0/). 